\title{
Preferensi Wisatawan Terhadap Destinasi Wisata Pantai Camplong Kabupaten Sampang
}

\author{
Ika Nur Wahyuni ${ }^{1}$, Novi Diana Badrut Tamami ${ }^{1 *}$ \\ ${ }_{1}^{1}$ Program Studi Agribisnis Fakultas Pertanian Universitas Trunojoyo Madura \\ Jl. Raya Telang No 02 Kamal Bangkalan Madura 69162 Jawa Timur \\ *Email: novi@trunojoyo.ac.id
}

Naskah diterima 12 Desember 2020, Revisi 15 Maret 2021, Terbit 29 April 2021

\begin{abstract}
DOI: doi.org/10.21107/pamator.v14i1.9536

The business competition of service industry recently is very competitive especially in tourism sector, which involves various economic sectors. Tourist's desire visits a tourist destination influenced by tourist preferences. The purpose of this study are: (1) to determine the characteristics of Camplong beach in Sampang Regency'svisitors, (2) knowing tourist's preferences for attributes and attribute's level in tourist visitation to Camplong beach in Sampang Regency. The research method uses descriptive and conjoint analyze. The results show that the characteristics of tourists are mostly dominated by school students or college students with average of age in 15-65 years old, this category visitors usually travels with their friends or family whose unmarried status with income of $<R p 1,000,000.00$. The attributes chosen by tourists are tourism activities which is motorcycle tracks, motorcycle transportation, restaurant accommodations, beach facilities such as photo spots and souvenir types, include clothes.
\end{abstract}

Key words: tourism industry, consumer behaviours, preferences

\section{PENDAHULUAN}

Indonesia terkenal memiliki banyak keanekaragaman wisata yang begitu indah. Pengembangan usaha pariwisata didukung dengan Undang-Undang Republik Indonesia No 10 Tahun 2009 bahwa keberadaan objek wisata pada suatu daerah akan sangat menguntungkan karena dapat meningkatkan Pendapatan Asli Daerah (PAD), meningkatkan rasa peduli terhadap lingkungan serta dapat melestarikan alam dan budaya (Yusran dan Oktavianus, 2013). Pengembangan Obyek dan Daya Tarik Wisata (ODTW) menjadi penggerak utama dalam pengembangan sektor pariwisata. Daya tarik dari obyek wisata adalah salah satu modal utama dalam pengembangan ODTW.

Hal ini terjadi karena potensi dan daya tarik obyek wisata menjadi faktor penting bagi wisatawan untuk mengunjungi wisata tersebut (Devy dan Soemanto, 2017). Objek Wisata di Jawa Timur yang mulai menunjukkan pengembangannya yaitu ada di Kabupaten Sampang. Dalam Rencana Induk Pengembangan Pariwisata (RIPPDA) Kabupaten Sampang 2015, tujuan wisata utama, yang berada di Kabupaten Sampang antara lain yaiutu pantai Camplong, pantai
Nepa, dan air terjun Toroan. Ketiga tujuan wisata tersebut merupakan wisata di kawasan pesisir. Sebelum muncul objek wisata baru di Sampang, Pantai Camplong menjadi destinasi wisata primadona masyarakat. Setiap musim libur, pantai tersebut senantiasa diserbu pengunjung baik dari lokal Sampang ataupun dari berbagai kabupaten terdekat. Pada Tabel 1 berikut bisa dilihat Jumlah wisatawan lokal yang berkunjung ke Pantai Camplong.

Tabel 1. Jumlah Pengunjung Wisatawan Lokal Kabupaten SampangTahun 2013-2018

\begin{tabular}{llrrrrrr}
\hline$N$ & \multirow{2}{*}{ Nama Wisata } & \multicolumn{7}{c}{ Tahun (Wisatawan) } \\
\cline { 2 - 8 } 0 & & \multicolumn{1}{c}{2013} & 2014 & 2015 & 2016 & 2017 & 2018 \\
\hline 1 & Pantai Camplong & 7.518 & 11.800 & 16.060 & 17.643 & 42.448 & 8.222 \\
2 & Hutan Kera Nepa & 1.772 & 2.560 & 4.046 & 7.669 & 28.370 & \\
3 & Air Teriun Toroan & 920 & 1.512 & 2.653 & 4.163 & 15.556 & \\
4 & Gua Lebar & 3.672 & 4.682 & 6.855 & 8.076 & 8.496 & \\
5 & Kolam Renang Sumber & 3.248 & 5.781 & 8.069 & 7.833 & 3.179 & \\
& Oto' & & & & & & \\
\hline
\end{tabular}

Sumber : Dinas Pemuda Olahraga Budaya dan Pariwisata Kabupaten Sampang, 2019

Pantai Camplong saat ini mulai kalah bersaing, semenjak muncul wisata-wisata baru, para pelancong lebih memilih pantai lain. Berdasarkan catatan di Disporabudpar, kunjungan wisatawan tertinggi saat ini 
dipegang Pantai Lon Malang, yang merupakan wisata baru di Tahun 2018. Kunjungan wisatawan ke Lon Malang mencapai 78.862 orang, sementara kunjungan ke Camplong mencapai 8.222 orang menempati urutan ketiga, pada urutan kedua Hutan Kera Nepa dengan kunjungan 28.253 orang.

Kunjungan ke kawasan wisata pantai Camplong, belum didukung dengan manajemen yang baik oleh pihak pengelola, sehingga muncul beberapa permasalahan seperti pelayanan yang belum memadai baik dari aspek daya tarik wisata, aksesibilitas yang memadai, fasilitas wisata, serta promosi dan informasi yang dapat menarik wisatawan untuk berkunjung. Saat ini kondisi Pantai Camplong semakin memprihatinkan, bahkan terkesan kurang terurus, lantaran sampah berserakan dan sejumlah fasilitas penunjang wisata banyak yang dibiarkan rusak dan karatan. Permasalahan yang ada tidak mengurangi minat wisatawan untuk mengunjungi kawasan wisata pantai Camplong.

Permasalahan tersebut muncul karena pengelola belum memahami preferensi wisatawan yang menjadi salah satu komponen pariwisata yang utama. Wisatawan memiliki preferensi yang berbeda terhadap kawasan wisata pantai Camplong dan menyimpan daya tarik tersendiri bagi warga Kota Sampang dan sekitarnya. Sehingga pengelola pantai Camplong harus mengetahui keinginan pengunjung atau wisatawan dan memberikan yang terbaik untuk pengunjungnya, yang nantinya akan terjadi timbal balik antar pengelola dengan pengunjung berupa informasi yang diinginkan oleh pengunjung dan dapat dijadikan evaluasi bagi pengelola supaya lebih berkembang. Oleh karena itu perlu adanya penelitian mengenai preferensi pengunjung terhadap destinasi wisata di Pantai Camplong

\section{METODOLOGI}

Penelitian ini dilakukan di pantai Camplong Kecamatan Camplong Kabupaten Sampang pada bulan Februari 2020. Lokasi penelitian dipilih secara sengaja (purposive) dengan pertimbangan bahwa (1) Pantai Camplong menjadi destinasi wisata primadona masyarakat karena letaknya yang strategis dekat dengan jalan raya dan pastinya dilewati oleh kendaraan yang akan menuju ke kabupaten pamekasan dan Kabupaten Sumenep; (2) Semenjak muncul wisata baru pantai di tahun 2018 jumlah pengunjung pantai Camplong mengalami menurunan dan mulai kalah pamor. Sumber data dalam penelitian ini menggunakan data primer dan data sekunder. Pengumpulan data primer diperoleh secara langsung dari wisatawan yang berkunjung ke Pantai Camplong yang dilakukan dengan metode wawancara menggunakan kuisioner untuk memperoleh data dan informasi yang dibutukan peneliti. Selanjutnya data sekunder diperoleh dari hasil publikasi lembaga atau dinas terkait, jurnal, buku, dan literature lainnya yang mendukung data primer.

Metode penentuan sampel pada penelitian ini yakni menggunakan accidental sampling, yaitu siapa saja yang secara kebetulan bertemu dengan peneliti dapat digunakan sebagai sampel apabila dipandang responden tersebut cocok sebagai sumber data. Berdasarkan Sugiyono (2011), penelitian ini akan diambil 30 responden karena ukuran sampel yang layak untuk digunakan dalam suatu penelitian adalah antara 30 sampai dengan 500 responden. Kriteria penentuan sampel responden yakni siapa saja yang bertemu peneliti di Pantai Camplong dan pernah mengunjungi Pantai Camplong minimal 1 kali, baik itu perempuan ataupun laki-laki yang berusia lebih dari 15 tahun dan dibawah 65 tahun, karena pada usia tersebut dianggap dapat memberikan informasi yang jelas dan terpercaya dalam penelitian ini.

Metode analisis data yang dilakukan dalam penelitian ini menggunakan analisis deskriptif untuk mendeskripsikan karakteristik wisatawan dan analisis conjoint. Analisis Conjoint menurut Idrus (2013) dipergunakan untuk melihat seberapa penting (relative important) suatu atribut pada suatu produk/jasa ketika produk/jasa tersebut di evaluasi oleh seorang konsumen sebelum produk tersebut dibeli. Tahapan dalam melakukan analisis Conjoint menurut Gudono (2012) ialah : (1) Menentukan atribut \& level atribut, (2) membuat kombinasi produk (stimuli), (3) melakukan ranking menggunakan Skala 
Likert terhadap stimuli yang ada, (4) Menentukan atribut yang menjadi preferensi wisatawan dan nilai utilitas untuk mengetahui level atribut yang paling diinginkan oleh wisatawan. Penelitian ini menggunakan 6 atribut dengan masingmasing atribut terdiri atas 2 sampai 4 taraf atau level atribut.

Tabel 2. Atribut dan Level Atribut pada Wisata Pantai

\begin{tabular}{cc}
\hline \multicolumn{1}{c}{ Atribut } & Level Atribut \\
\hline Aktivitas Wisata $\left(\alpha_{1}\right)$ & Trek Motor $\left(\alpha_{11}\right)$ \\
Transportasi $\left(\alpha_{2}\right)$ & Berenang $\left(\alpha_{12}\right)$ \\
& Bus $\left(\alpha_{21}\right)$ \\
& Mobil Pribadi $\left(\alpha_{22}\right)$ \\
Jenis Akomodasi $\left(\alpha_{3}\right)$ & Sepeda Motor $\left(\alpha_{23}\right)$ \\
& Penginapan atau Hotel \\
& $\left(\alpha_{31}\right)$ \\
& Restaurant $\left(\alpha_{32}\right)$ \\
Fasilitas Pantai $\left(\alpha_{4}\right)$ & Situs Berkemah $\left(\alpha_{33}\right)$ \\
& Taman Bermain $\left(\alpha_{41}\right)$ \\
& Spot Foto $\left(\alpha_{42}\right)$ \\
& Pasar Wisata $\left(\alpha_{43}\right)$ \\
Jenis Cenderamata $\left(\alpha_{5}\right)$ & Perahu Layar $\left(\alpha_{44}\right)$ \\
& Souvenir $\left(\alpha_{61}\right)$ \\
& Makanan Khas $\left(\alpha_{62}\right)$ \\
& Pakaian $\left(\alpha_{62}\right)$ \\
\hline
\end{tabular}

HASIL PEMBAHASAN

Karakteristik Responden Berdasarkan Jenis Kelamin

Hasil penelitian karakteristik responden berdasarkan jenis kelamin diketahui bahwa, responden pada penelitian ini yang berjenis kelamin laki-laki lebih banyak dibandingkan dengan responden yang berjenis kelamin perempuan. Total jumlah responden laki-laki sebanyak $60 \%$ atau 18 orang dan hanya sebanyak $40 \%$ atau 12 untuk responden perempuan. Meskipun hasil penelitian diketahui pengunjung laki-laki lebih dominan dari perempuan, tetapi perbedaan itu tidak begitu signifikan. Maka dari itu, Pantai Camplong merupakan obyek wisata yang banyak diminati oleh semua gender atau kalangan. Sehingga untuk melakukan pengembangan kawasan wisata tidak dilihat berdasarkan pada perbedaan jenis kelamin akan tetapi bisa diperhatikan hal-hal yang juga diperuntukkan secara umum. Kondisi ini sejalan dengan penelitian Jayaprakash (2016), bahwasanya laki - laki lebih menyukai kegiatan wisata ke objek wisata alam.

\section{Karakteristik Responden Berdasarkan Usia}

Tingkat usia responden dapat diketahui bahwa $100 \%$ responden berada pada usia 15-40 tahun. Pada kelompok usia ini mereka merupakan yang senang bepergian mengunjungi tempat wisata bersama temanteman atau pasangan mereka, pada kelompok usia ini juga terdapat responden keluarga kecil dan umumnya telah memiliki anak balita. Kelompok ini pada umumnya yakni usia produktif dengan kesehatan yang baik, sehingga di usia ini diperkirakan orang semakin suka melangsungkan perjalanan. Sebaliknya kelompok umur yang paling sedikit mendatangi tempat wisata ialah kelompok usia dibawah 15 tahun dan diatas 40 - 65 tahun, umur diatas 65 tahun umumnya kelompok orang tua dan lansia. Secara umum kondisi pada kelompok usia itu dari segi kesehatan maupun produktivitasnya sudah sangat menurun. Berdasarkan pertimbangan bahwa Wisata Pantai Camplong ini lebih banyak pengunjung kelompok usia muda, maka untuk fasilitas-fasilitas wisata sebaiknya lebih diprioritaskan dan diperhatikan apa yang disukai oleh kelompok tersebut.

\section{Karakteristik Responden Berdasarkan Pendidikan}

Faktor penentu yang berpengaruh untuk melakukan pengambilan keputusan pembelian produk atau jasa salah satunya adalah tingkat pendidikan. Tingkat pendidikan seseorang bisa bermacammacam mulai dari tidak tamat SD, SD, SMP, SMA maupun Perguruan Tinggi. Adapun hasil dari pengisian kuisioner pada penelitian ini mengenai tingkat pendidikan dapat dilihat dalam presentase berikut:

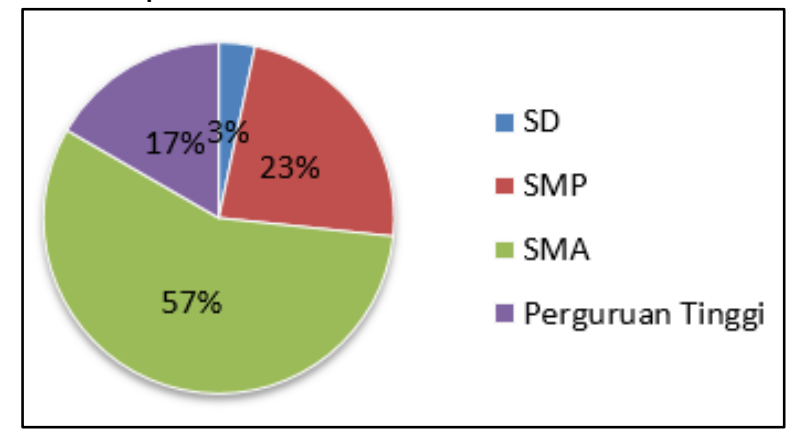

Gambar 1. Karakteristik Responden Berdasarkan Pendidikan 


\section{Karakteristik Responden Berdasarkan Pekerjaan}

Pekerjaan wisatawan yang berkunjung ke Pantai camplong didominasi oleh pelajar atau mahasiswa yaitu sebanyak $64 \%$ atau sebanyak 19 orang dan wiraswasta sebanyak $20 \%$ atau 6 orang. Hal ini disebabkan kedua kelompok pengunjung Wisata pantai Camplong ini memiliki kemiripan tujuan berkunjung yaitu berlibur untuk menghabiskan waktu luang dan melepaskan penat setelah hari-hari mereka disibukkan dengan rutinitas, aktifitas belajar bagi pelajar atau mahasiswa dan aktifitas pekerjaan wiraswata yang dikenal berat. Sesuai dengan pembahasan sebelumnya bahwa kelompok wisatawan terbanyak adalah berada pada kisaran umur 15-65 tahun. Mahasiswa atau pelajar ialah mereka yang berada dalan masa suka mencari pengalaman baru, pelajar atau mahasiswa cenderung suka bersama sahabat dalam melakukan aktivitasnya, tidak terkecuali dalam berkunjung ke obyek wisata.

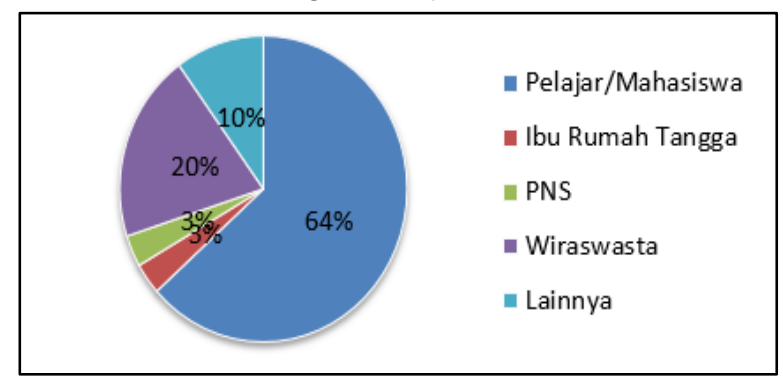

Gambar 2. Karakteristik Responden Berdasarkan Pekerjaan

\section{Karakteristik Responden Berdasarkan Pendapatan}

Hasil penelitian menunjukkan bahwa wisatawan sebagian besar mempunyai income berkisar < Rp 1.000.000,00 dengan presentase $80 \%$ dari total responden atau sebanyak 24 orang, sedangkan wisatawan yang memiliki pendapatan berkisar antara $\mathrm{Rp}$ $1.000 .000,00 \mathrm{~s} / \mathrm{d}$ kurang dari $\mathrm{Rp}$ $5.000 .000,00$ yaitu sebesar $7 \%$ atau masingmasing sebanyak 2 orang saja. Hal ini disebabkan wisatawan yang hadir didominasi oleh pelajar atau mahasiswa yang mempunyai waktu luang untuk berwisata namun masih belum memiliki penghasilan. Menurut Yoeti (2013) tidak akan ada artinya jika memiliki pendapatan yang besar namun tidak memiliki waktu luang untuk melakukan perjalanan wisata. Maka dengan demikian paket-paket yang diberikan dan disediakan oleh obyek wisata harus memperhatikan sisi finansial pengunjung demi menetapkan harga yang cukup terjangkau dikalangankpelajar atau mahasiswa. Begitu pula halnya dengan lokasi membeli cinderamata maupun oleh-oleh dan kuliner sehingga terjangkau oleh mayoritas kelompok tersebut.

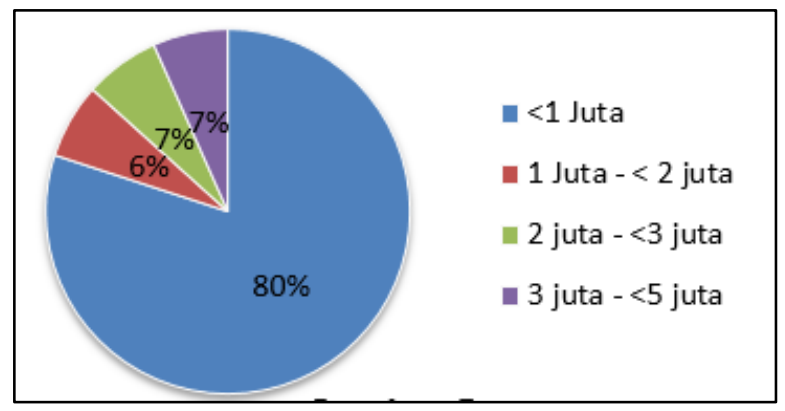

Gambar 3. Karakteristik Responden Berdasarkan Pendapatan

\section{Karakteristik Responden Berdasarkan Motivasi Wisata}

Perilaku manusia dipengaruhi oleh berbagai motivasi. Motivasi merupakan pendorong utama wisatawan untuk melakukan kunjungan wisata. Dikaji dari sisi motivasi wisatawan datang ke wisata Pantai Camplong, didominasi oleh keindahan pantai sebanyak $87 \%$ atau 26 orang. Motivasi wisatawan berikutnya adalah ragam budaya sebanyak $7 \%$ atau sebanyak 2 orang. Motivasi yang lain yaitu adanya sarana permainan, aneka kuliner yang disajikan atau alasan lainnya.

Menurut Yoeti (2013), permintaan dalam kepariwisataan dapat berupa benda bebas (free - goods) yang bisa diperoleh tanpa membeli, namun menjadi daya tarik bagi wisatawan sebagai objek pariwisata, misalnya pemandangan alam, laut, danau, sungai, dan sebagainya. Hal ini sejalan dengan data dimana responden mayoritas memilih memilih keindahan pantai. Karena mayoritas pengunjung yang melakukan kunjungan termotivasi dari keindahan pantai, maka strategi pengembangan yang dibutuhkan adalah meningkatkan estetika dan melindungi keadaan alami pantai yamg terdapat di area wisata pantai Camplong dengan meningkatkan pengelolaan kebersihan pantai dalam hal pengelolaan 
sampah di sekitar pantai, pembuangan limbah cair, daur ulang sampah, penyediaan air bersih, dan juga pengadaan fasilitas kebersihan.

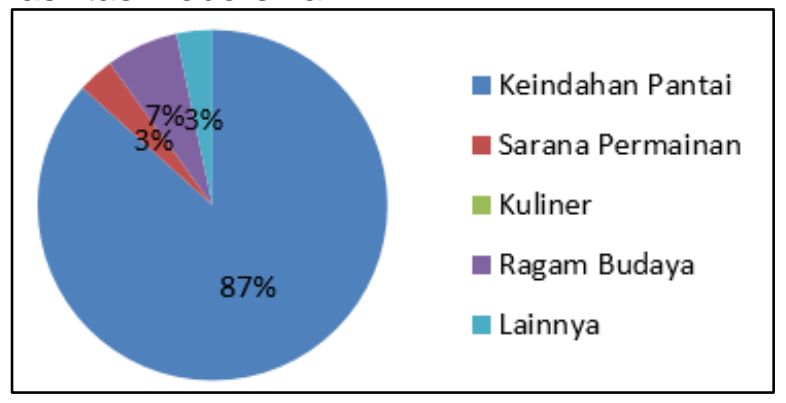

Gambar 4. Karakteristik Responden Berdasarkan Motivasi

\section{Karakteristik Responden Berdasarkan Biaya/ Hari}

Biaya yang dikeluarkan oleh mayoritas wisatawan untuk berwisata ke Pantai Camplong dalam kurun waktu sehari adalah $<$ Rp. $100.000,00$ yaitu sebanyak $77 \%$ atau sebanyak 23 orang dan Rp 100.000,00 - Rp $150.000,00$ sebanyak $10 \%$ atau sebanyak 3 orang. Biaya yang dikeluarkan sudah keseluruhan pengeluaran termasuk tiket masuk, makan dan souvenir. Jika dibandingkan dengan biaya berwisata ke objek yang lain biaya tersebut masih dianggap relatif murah dan terjangkau.

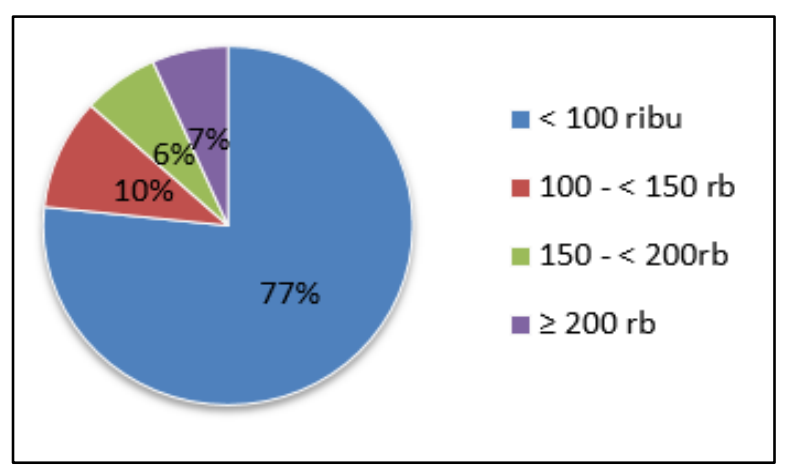

Gambar 5. Karakteristik Responden Berdasarkan Biaya/ Hari

Hal ini berhubungan dengan data sebelumnya bahwa mayoritas pengunjung adalah mahasiswa atau pelajar yang belum memiliki penghasilan. Data sebelumnya juga menunjukkan banyak wisatawan datang hanya satu hari sehingga tidak butuh pengeluaran akan biaya akomodasi. Bagi wistawan yang berkunjung bersama kerabat banyak juga dijumpai yang membawa bekal dari rumah berupa makanan, minuman dan alas duduk, cara ini bisa digunakan dengan alasan demi menghemat pengeluaran.

\section{Preferensi Wisatawan Terhadap Destinasi Wisata di Pantai Camplong}

Preferensi wisatawan terhadap destinasi wisata di pantai Camplong merupakan tujuan kedua dalam penelitian ini dengan menggunakan analisis Conjoint. Hasil dari analisis untuk uji signifikansi atribut dapat diketahui pada Tabel 3.

Tabel 3. Nilai Signifikansi Atribut Destinasi Wisata Pantai Camplong

\begin{tabular}{lcc} 
& Value & Sig. \\
\hline $\begin{array}{l}\text { Pearson's } \\
\text { R }\end{array}$ & .974 & .000 \\
$\begin{array}{l}\text { Kendall's } \\
\text { tau }\end{array}$ & .920 & .000 \\
\hline
\end{tabular}

Berdasarkan hasil analisis konjoin pada tabel 3 dapat diketahui bahwa, hasil nilai predictive accuracy pada peringkat perason's dan kendall's tau sebesar 0,00 yang mana nilai ini lebih kecil dari taraf kesalahan 0,05 $(0,00<0,05)$. Maka dari itu dapat disimpulkan bahwa penelitian ini dianggap valid sebab angka predictive accuracy pada peringkat Pearson's dan Kendall's menunjukkan hasil korelasi yang signifikan. Hasil analisis ini juga terdapat nilai Pearson'R sebesar 0,974 atau $97,4 \%$ menunjukkan bahwa terdapat keterkaitan yang tinggi antara preferensi wisatawan di Pantai Camplong dengan profil atribut destinasi wisata. Dengan kata lain preferensi wisatawan sebesar 97,4\% dipengaruhi oleh kombinasi atribut yang ada dalam kuisioner. Sedangkan sisanya sebesar $2,6 \%$ dipengaruhi oleh faktor lain yang selain pada model atau di luar model. Dengan demikian dapat disimpulkan bahwa pendapat dari 30 responden tersebut dapat diterima untuk menggambarkan preferensi wisatawan terhadap destinasi wisata di pantai Camplong.

Analisis konjoin pada penelitian ini juga dapat menghasilkan nilai utility. Nilai utility menunjukkan tingkatan atribut dan level atribut dari yang paling disukai oleh wisatawan. Nilai utility dari atribut serta level atribut dapat diketahui dalam bentuk stimuli yang paling disukai maupun yang paling tidak disukai oleh wisatawan. Adapun nilai utility dari atribut dan level atribut pada destinasi 
wisata di Pantai Camplong bisa diketahui di tabel sebagai berikut.

Tabel 4. Nilai Koefisien Utility Atribut dan Level Atribut Destinasi Wisata Pantai Camplong

\begin{tabular}{llc}
\hline Atribut & Level Atribut & Utility Estimate \\
\hline Aktivitas_Wisata & Trek Motor & .008 \\
& Berenang & -.008 \\
Transportasi & Bus & -.261 \\
& Mobil Pribadi & .068 \\
Akomodasi & Sepeda Motor & .193 \\
& Penginapan & -.022 \\
& Restauran & .011 \\
& Situs & .011 \\
Fasilitas_Pantai & Berkemah & \\
& Taman & -.008 \\
& Bermain & .125 \\
& Spot Foto & .017 \\
& Pasar Wisata & -.133 \\
& Perahu Layar & -.028 \\
Jenis_Cenderamata & Souvenir & -.065 \\
& Makanan & .093 \\
& Khas & 2.636
\end{tabular}

Berdasarkan tabel 4 dapat diketahui nilai utility pada setiap atribut dan level atribut. Pada level atribut aktivitas wisata trek motor memiliki nilai utility sebesar 0,008 yang lebih besar dibandingkan aktivitas wisata berenang. Hal ini karena wistawan yang berkunjung ketika sore hari khususnya melakukan aktivitas trek motor disekitar pasir pantai, terlebih lagi saat ini disediakan jasa tempat sewa trek motor sehingga wisatawan lebih memilih aktivitas trek motor sebagai kegiatan favoritnya terutama pengunjung laki-laki. Wisatawan yang berkunjung ke pantai Camplong dengan aktivitas berenang lebih sedikit, hal ini karena kondisi air di pantai camplong tidak bening dan air laut merupakan air yang asin sehingga tidak cocok jika digunakan untuk aktivitas berenang, kecuali wisatawan yang berkunjung dengan keluarga dan membawa anak kecil sekitar umur 3-10 tahunan akan melakukan aktivitas berenang bersama anaknya. Fakta ini berkorelasi dengan analisis sebelumnya dalam karakteristik responden yang menyebutkan bahwa dari total 30 responden, mayoritas didominasi oleh laki-laki dibandingkan dengan responden yang berjenis kelamin perempuan, sehingga nillai utility pada aktivitas trek motor yang biasanya merupakan aktivitas favorit wisatawan lakilaki lebih besar ddibandingkan aktivitas berenang.

Pada atribut transportasi wisatawan lebih menyukai transportasi menggunakan sepeda motor karena nilai utility pada transportasi sepeda motor $(0,193)$ lebih besar dari mobil pribadi $(0,68)$ dan bus atau transportasi umum $(-0,261)$. Banyaknya wisatawan yang memilih menggunakan transportasi berupa sepeda motor karena wisatawan yang berkunjung didominasi oleh wisatawan dari madura khususnya dari Sampang dibandingkan dari luar madura sehingga pengunjung lebih memilih transportasi sepeda motor. Wsatawan yang memilih transportasi umum berupa mobil pribadi maupun bus atau kendaraan umum adalah wisatawan yang lokasinya jauh dari pantai camplong, biasanya dari luar Madura. Wisatawan yang menggunakan transportasi berupa bus yaitu wisatawan yang perjalannya memakai jasa biro wisata atau paket wisata, baik itu melakukan kunjungan dan lain-lain. Dengan demikian, strategi pengembangan yang diperlukan pengelola yaitu peningkatan kualitas perparkiran dengan dilakukannya perluasan tempat parkir, pengadaan karcis parkir resmi, dan perkerasan lahan parkir, dapat mengakomodasi kebutuhan pengunjung yang didominasi oleh kendaraan sepeda motor.

Nilai utility yang terbesar pada atribut akomodasi terdapat pada akomodasi berupa restaurant dan situs berkemah dengan nilai utility masing-masing sebesar 0,011 dibandingkan dengan akomodasi berupa penginapan atau hotel $(-0,022)$. Wisatawan merasa akomodasi restaurant dan situs berkemah pada wisata Pantai Camplong lebih penting dibandingkan penginapan. Perlu diketahui bahwa karakteristik wisatawan pada penelitian ini mayoritas adalah pelajar atau mahasiswa dengan status belum menikah dan berkunjung hanya satu hari tanpa menginap. Hal ini sejalan dengan penelitian Koranti et al. (2017), dimana peferensi wisatawan terhadap akomodasi dipengaruhi oleh tujuan wisata dan lama wisatawan melakukan kunjunangana. Hal ini berkorelasi dengan 
data yang menunjukkan bahwa penginapan kurang penting di kalangan pelajar atau mahasiswa karena tujuan wisata wisatawan hanya untuk berlibur dan waktu kunjungan hanya sehari saja. Untuk biaya penginapan terbilang mahal sedangkan per hari wisatawan mayoritas mengeluarkan uang $<$ Rp 100.000,00. Menurut Suanmali (2014) biaya menginap termasuk harga akomodasi, makanan dan minuman, transportasi, produk, dan biaya menginap keseluruhan, dimana jika harga menginap meningkat, kepuasan wisatawan akan berkurang. Kalangan mahaiswa atau pelajar yang berkunjung bersama teman-temannya lebih mementingkan akomodasi restaurant untuk tempat makan mereka dan sebagian dari mahasiswa atau pelajar ini juga menghabiskan waktunya dengan camping sehinga situs berkemah dianggap penting dibandingkan penginapan karena tidak berbayar dan low budget.

Pada tingkat atribut fasilitas pantai wisatawan cenderung menyukai fasilitas pantai berupa spot foto dengan nilai utility sebesar 0,125 yang paling besar dibanding dengan level atribut lainnya. Kasus ini responden atau wisatawan menunjukkan bahwa spot foto merupakan fasilitas yang sering digunakan oleh wisatawan. Hal ini sejalan dengan karakteristik responden yang mayoritas dari kalangan pemuda yaitu pelajar atau mahasiswa. Seluruh kalangan baik itu anak-anak, remaja, dewasa, bahkan manula, berlomba-lomba untuk mengabadikan momen mereka ketika bepergian ke tempat wisata dengan berfoto.Fenomena ini ini telah menjadi hal yang menarik untuk remaja milenial, terutama untuk mereka yang narsis akibat kecanduan berfoto, sehingga destinasi wisata yang memiliki spot foto yang menarik menjadi incaran dan menjadi tren foto masa kini. Dengan demikian, pihak pengelola melakukan strategi pengembangan dengan menyediakan fasilitas pariwisata sesuai dengan preferensi pengunjung.

Atribut jenis cenderamata, Responden lebih memilih cenderamata berupa pakaian dengan nilai utility sebesar 0.093 yang lebih besar dibandingkan dengan level atribut jenis cenderamata lainnya yakni souvenir $(-0,028)$ dan makanan khas $(-0,65)$. Sebagian besar wisatawan menganggap cenderamata berupa pakaian merupakan jenis cendramata yang tepat. Cenderamata terlepas dari berapapun harganya merupakan tanda mata ungkapan cinta kasih seorang wisatawan kepada kerabat maupun sahabat yang sudah menanti nanti kepulangan mereka setelah bepergian. Cinderamata atau oleh-oleh seolah-olah menjadi bagian yang tidak terpisahkan dari perjalanan wisata yang seorang tuju. Setelah menuju beberapa destinasi wisata tentu menjadi kurang lengkap apabila hanya pulang dengan tangan hampa tanpa membawa pakaian atau kaos khas madura yaitu baju sakera atau baju marlena dengan ciri kaos liri-liris merah putih untuk laki-laki dan kebaya merah untuk perempuan yang dijual pasar wisata maupun ruko tempat oleh-oleh di sekitar Pantai Camplong.

Setiap orang tentunya akan mempertimbangkan atribut dari suatau produk atau jasa yang akan dibelinya. Setelah mengetahui nilai koefisien utility preferensi wisatawan terhadap destinasi wisata di Pantai Camplong selanjutnya mengetahui tingkat kepentingan atribut atau bobot kepentingan relatif. Bobot kepentingan trelatif pada atribut yang menjadi pertimbangan wisatawan dapat dilihat pada tabel berikut ini.

Tabel 5. Tingkat Kepentingan Atribut Destinasi Wisata Pantai Camplong

\begin{tabular}{cc}
\hline Atribut & Tingkat Kepentingan Atribut \\
\hline Aktivitas Wisata & 13.494 \\
Transportasi & 24.856 \\
Akomodasi & 18.504 \\
Fasilitas Pantai & 26.490 \\
Jenis_Cenderamata & 16.656 \\
\hline
\end{tabular}

Dari tabel diatas diperoleh hasil nilai kepentingan masing-masing atribut mulai dari peringkat yang terendah sampai peingkat yang tertinggi yang menjadi pertimbangan pemilihan konsumen dalam membeli jasa di Pantai Camplong. Pada atribut fasilitas pantai memiliki tingkat kepentigan paling tinggi ialah 26,490 dibandingkan atribut lainnya. Dalam hal ini menunjukkan bahwa wisatawan di Pantai Camplong lebih memperhatikan dan mementingkan fasilitas pantai dibandingkan dengan atribut lainnya. Selain itu fasilitas di Pantai Camplong dibilang cukup lengkap, baik itu penginapan, restoran, pasar wisata, 
taman bermain, area outbound. Sehingga perlu diperhatikan dan dievaluasi mengenai fasilitas pantai agar ada inovasi lainnya yang bisa dilakukan oleh pihak pengelola untuk memberi fasilitas baru yang dengan menyediakan, memperbanyak, dan memelihara kondisi fasilitas kebersihan meliputi tempat ibadah, toilet, kamar mandi, bak sampah, dan satuan pet ugas kebersihan di setiap lokasi wisata.

Pertimbangan atribut kedua yang dipilih wisatawan yakni transportasi dimana tingkat kepentingan atribut trasnportasi sebesar 24,856 . Berdasarkan hasil pada tabl diatas menunjukkan bahwa transportasi menjadi atribut yang dipertimbangkan atau dipilih oleh responden setelah fasilitas pantai.Sejalan dengan penelitian Parasto et al., (2018), yang menunjukkan bahwa transportasi merupakan atribut terpenting kedua dan sub atribut terpenting dari atribut transportasi adalah transportasi pribadi. Berdasarakan faktor yang mempengaruhi wisatawan dalam melakukan perjalanan wisata yang dikemukakan oleh Yoeti (2013) diantaranya adalah teknologi pengangkutan (transportasi), yang dapat mempercepat waktu untuk menempuh jarak yang cukup jauh dengan berbagai fasilitas serta pelayanan yang menarik, banyak sekali mendorong wisatawan untuk melakukan kunjungan pariwisata. Dengan demikian pihak pengelola perlu menyediakan serta menjaga sarana transportasi umum dari jalan raya menuju lokasi-lokasi wisata, memperbaiki dan memelihara kondisi jalan.

Pertimbangan atribut yang ketiga yakni akomodasi dimana tingkat kepentingan atribut sebesar 18,504. Berlandaskan hasil tersebut dapat diketahui bahwa atribut yang dipertimbangkan oleh wisatawan dalam melancarkan perjalanan wisata ke Pantai Camplong setelah fasilitas pantai dan transportasi adalah akomodasi. Sehingga penting bagi pengelola wisata untuk meperhatikan akomodasi dan meneyediakan akomodasi yang sesuai dengan keinginannya. Menurut Koranti et al., (2017), tujuan wisata dan lama wisatawan menjalankan kunjungan berpengaruh terhadap preferensi wisatawan dalam memilih akomodasi. Dengan demikian untuk pengembangan akomodasi yaitu dengan merencanakan akomodasi alternatif dengan konsep homestay berupa tempat tinggal masyarakat setempat sebagai bentuk perluasan akomodasi ke depan untuk memelihara interaksi masyarakat setempat terhadap pengunjung dan alam.

Pertimbangan atribut yang keempat yakni jenis cinderamata, pada tabel 3 diatas tingkat kepentingan atribut cinderamata sebesar 16,656. Berdasarkan hasil tersebut dapat diketahui bahwa atribut cinderamata ini dinilai penting bagi para wisatawan. Jenis Cinderamata atau oleh-oleh seolah sebagai bagian yang tidak terpisahkan dari perjalanan wisata yang seorang tuju, sehingga perlu diperhatikan untuk pihak pengelola agar menyediakan jenis cinderamata yang bermacam-macam agar wisatawan dapat memilih cinderamata yang sesuai dengan keinginannya. Hal ini berbeda dengan penelitian yang dilakukan oleh Kembaren (2014) bahwa atribut cenderamata berada pada urutan ketiga yang dipertimbangkan oleh wisatawan setelah atribut atraksi wisata dan aktivitas wisata. Sehingga rekomendasi strategi yang dilakukan yaitu dengan menggunakan jasa masyarakat setempat untuk peningkatan usaha pariwisata berupa kios cinderamata, pedagang makanan dan minuman khas Camplong, oleh-oleh, dan souvenir.

Pertimbangan terakhir wisatawan dalam mengunjungi wisata Pantai Camplong yakni aktivitas wisata dengan tingkat kepentingan atribut sebesar 13,494. Berdasarkan hasil tersebut maka dapat diketahui wisatawan pada Pantai Camplong lebih mengutamakan atribut lain saat melakukan perjalanan wisatanya dibandingkan dengan aktivitas wisata itu sendiri. Penelitian ini berbanding terbalik dengan yang dilakukan oleh Parasto et al., (2018) dimana atribut dan sub atribut yang menjadi preferensi wisatawan terhadap destinasi wisata kota Semarang adalah aktivitas wisata dan sub atribut terpenting dari atribut aktivitas wisata adalah wisata sejarah. Dengan demikian maka strategi pengembangan oleh pihak pengelola sebaiknya dengan meningkatkan jumlah aktivitas wisata berupa makan dipantai, ber perahu, snorkling, diving dan memancing di lokasi 


\section{KESIMPULAN}

Karakteristik wisatawan yang berkunjung ke destinasi wisata di Pantai Camplong diketahui sebagian besar didominasi oleh pelajar atau mahasiswa dengan rata-rata usia 15-65 tahun, kelompok ini biasanya melakukan perjalanan wisata bersama teman atau kerabatnya yang statusnya mayoritas belum menikah dengan penghasilan $<R p$ 1.000.000,00. Wisatawan terbanyak berasal dari Madura dengan tujuan untuk berlibur dengan lama wisata 1 hari, wisatawan melakukan perjalanan wisata secara mandiri dengan menghabiskan biaya per hari $<R p$ $100.000,00$. Preferensi wisatawan terhadap destinasi wisata di pantai Camplong Kabupaten Sampang berdasarkan nilai utility yakni wisatawan lebih menyukai aktivitas wisata berupa trek motor, transportasi sepeda motor, akomodasi restaurant, fasilitas pantai berupa spot foto dan jenis cendramata yaitu pakaian. Sedangkan berdasarkan nilai kepentingan atribut wisatawan lebih mempertimbangkan fasilitas pantai, transportasi, akomodasi, jenis cinderamata dan aktivitas wisata.

Saran yang dapat diberikan dalam penelitian ini ialah pengelola perlu memperhatikan dan mengevaluasi mengenai fasilitas pantai agar ada inovasi lainnya yang bisa dilakukan oleh pihak pengelola untuk memberi fasilitas baru serta menambah spot-spot foto kekinian agar menarik minat wisatawan untuk berkunjung, menyediakan, menambah, dan menjaga kondisi fasilitas meliputi tempat ibadah, toilet, kamar mandi, tempat sampah, dan petugas kebersihan di setiap area wisata. Artinya, dengan fasilitas yang semakin baik, maka akan semakin membuat betah wisatawan. Apalagi kalau destinasi wisata memiliki akses yang mudah dijangkau. Kemudian pihak pengelola perlu menyediakan serta menjaga sarana transportasi umum dari jalan raya menuju lokasi-lokasi wisata, memperbaiki dan memelihara kondisi jalan. Serta merencanakan akomodasi alternatif dengan konsep homestay berupa tempat tinggal penduduk setempat sebagai bentuk perluasan akomodasi ke depan untuk menjaga interaksi penduduk setempat terhadap pengunjung dan alam. Serta melibatkan jasa masyarakat setempat untuk peningkatan usaha pariwisata berupa kios cinderamata, penjual makanan dan minuman khas, oleh-oleh, dan souvenir meneyediakan akomodasi yang sesuai dengan keinginan wisatawan. Pengelola dan masyarakat setempat bekerjasama menjaga kondisi alami pantai dalam hal pengelolaan sampah yang terdapat di kawasan wisata pantai Camplong. Berdasarkan pertimbangan bahwa Pantai Camplong lebih banyak pengunjung kelompok usia muda, dengan demikian maka strategi pengembangan oleh pihak pengelola sebaiknya dengan meningkatkan jumlah aktivitas wisata berupa makan dipantai, berperahu, snorkling, diving dan memancing di lokasi.

Jika atribut penting terjaminnya pariwisata daerah sudah berjalan baik, langkah selanjutnya adalah memiliki ujung tombak promosi, diharapkan agar pihak pengelola lebih giat dalam melakukan promosi. Maka, posisi duta wisata menjadi signifikan disini, keberadaan duta wisata akan mempermudah penyebaran informasi tentang pariwisata daerah kepada masyarakat luas hingga ke daerah lain. Saat ini, promosi konvensional tidak bisa terlalu diandalkan. Internet-lah yang menjadi tulang punggung baru untuk promosi pariwisata daerah. Pengelola harus memiliki website tentang potensi wisata pantai Camplong dan diperbarui secara rutin. Selain website, media sosial saat ini juga menjadi faktor yang menentukan keberhasilan promosi yang efektif dan tidak memakan waktu lama seperti mengadakan lomba video pendek mengenai pantai camplong yang nantinya setiap peserta yang ikut harus mengupload di youtube, kemudian bisa juga dengan lomba foto selfie di pantai camplong dengan memberi caption semenarik dan di upload ke instagram

\section{DAFTAR PUSTAKA}

Adomaitienè, Roma \& Javid Seyidov. 2016 Factors Influencing Local Tourists' Decision-Making On Choosing A Destination: A Case Of Azerbaijan. Journal Ekonomika. Vol. 95(3), Hal 112127. 
Agustini, N.W.A., Widyatmaja, I.G.N., \& Ariana I.N.J. (2018). Preferensi wisatawan terhadap pemilihan akomodasi di kabupaten bangli bali. Jurnal Kepariwisataan dan Hospitalis, 2(1), 2242.

Devy, H.A., \& Soemanto, R.B. 2017. Pengembangan Obyek Dan Daya Tarik Wisata Alam Sebagai Daerah Tujuan Wisata Di Kabupaten Karanganyar. Jurnal Sosiologi Dilema, 32(1), 34-44.

Dwiputra, Roby. (2013). Preferensi Wisatawan Terhadap Sarana Wisata Di Kawasan Wisata Alam Erupsi Merapi. Jurnal Perencanaan Wilayah dan Kota, 24 (1), 35-48.

Gudono. 2012. Analisis Data Multivariat. Yogyakarta: BPFE.

Hasedawa, T.S. 2017. Arahan Pengembangan Kawasan Wisata Pantai Nepa Berdasarkan Preferensi Pengunjung Kecamatan Banyuates Kabupaten Sampang. Tesis. Institut Teknologi Sepuluh November

Idrus, M.S. 2013. Multivariate Data Analisis dan Non Parametrik Statistik Untuk Penelitian Bidang Manajemen. Sidoarjo: Zifatama.

Jayaprakash, K. 2016. Factors Influencing The Tourists To Visit Udhagamandalam. International Journal of Management and Social Science Research Review. V0I 1 (25), Hal 40-44

Kembaren, Sari C. (2014). Preferensi Wisatawan Terhadap Kunjungan Wisata Pulau Samosir Dengan Analisis Konjoin. Jurnal Saintia Matematika, 2(3), 267-275.

Koranti, Komsi.,Sriyanto., \& Lestiyono, Sidik. (2017). Analisis Preferensi Wisatawan Terhadap Sarana Di Wisata Taman Wisata Kopeng. Jurnal Ekonomi Bisnis. 22(3), 242-254
Parasto, R.W., Suhendra, A.A., \& Tripiawan, Wawan. 2018. Analisis Preferensi Konsumen Terhadap Destinasi Wisata Kota Semarang Dengan Pendekatan Analisis Conjoint. Prosiding Teknik Industri. Desember 2018. Fakultas Rekayasa Industri Universitas Telkom.

Pauwah, Yusran et al., (2013). Persepsi Dan Preferensi Pengunjung Terhadap Kawasan Wisata Pantai Malalayang. Jurnal Sabua, 5(1), 16-27.

Peter, J. Paul., \& Olson, Jerry C. 2014. Perilaku Konsumen dan Strategi Pemasaran. Jakarta: Salemba Empat Umar, Husain. 2002. Riset Pemasaran dan Perilaku Konsumen. Jakarta : PT Gramedia Pustaka Utama.

Septiani, Emilia., Santoso, Budi., Mulyadi., \& Muhdin. 2019. Analisis Preferensi Pengunjung Kawasan Wisata Gili Meno Kabupaten Lombok Utara. Jurnal IImu Manajemen dan Bisnis, 7(2), 141-154.

Simamora, Bilson. Panduan Riset Perilaku Konsumen. 2003. Jakarta : PT. Gramedia Pustaka Utama.

Suanmali, S. 2014. Factors Affecting Tourist Satisfaction: An Empirical Study in the Northern Part of Thailand.

Sugiyono. 2011. Metode Penelitian Kuantitatif Kualitatif dan R\&D. Bandung: Alfabeta.

Suliyanto. 2009. Metode Riset Bisnis. Yogyakarta: Andi Offset.

Suryani, Tatik. 2008. Perilaku Konsumen Implikasi pada Strategi Pemasaran. Yogyakarta: Graha IImu.

Uyanto, Stanislaus S. 2009. Pedoman Analisis Data dengan SPSS. Yogyakarta: Graha IImu.

Yoeti, Oka A. 2013. Pemasaran Pariwisata. Bandung: Angkasa. 